\title{
THE IMPACT OF COVID-19 ON RURAL AREAS STUDENTS OF PAKISTAN: MODERATING ROLE OF HEC POLICY AND INTERNET SERVICE
}

\author{
Fatima Zahra ${ }^{1+}$ \\ Akhtar Gul ${ }^{2}$ \\ Anum Iqbal $^{3}$ \\ Tanbila Ghafoor ${ }^{4}$ \\ Ayesha Ambreen ${ }^{5}$
}

\author{
'Department of Economic, Women University Multan, Punjab, Pakistan. \\ Email:fatima_2sadam@yahoo.com \\ ${ }^{2}$ Goverment Post Graduate College Bannu, KPK, Pakistan. \\ Email:ilove.economicsso@yahoo.com \\ ${ }^{s}$ University of Gujrat, Punjab, Pakistan. \\ Email:amumbutt660@gmail.com \\ ${ }^{\text {}}$ University of Agriculture Faisalabad, Punjab, Pakistan. \\ Email:tanbila05@yahoo.com \\ ${ }^{5}$ Department of Economic, Women University Multan, Punjab, Pakistan. \\ Email:aveshaambreen1214@yahoo.com
}

(i) Check for updates

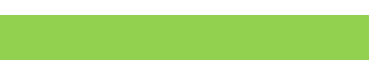

Article History

Received: 29 July 2020 Revised: 24 August 2020 Accepted: 2 September 2020 Published: 14 September 2020

\section{Keywords}

Covid-19

Issue of rural areas students

Internet expenditure

HEC policy

Pakistan.

\begin{abstract}
The purpose of this study is to investigate the significant impact of COVID-19 on rural areas students, in case of Pakistan. It is also a check on the moderating role of Higher education commission policy and access of internet services in providing the education facilities to the rural areas. This study adapted in depth analysis techniques and theoretical result find out that corona virus has knocked down the education of rural area student and incompatible role of Higher education of rural areas students. The ultimate evaluation method in education to compete the disaster situation taken by HEC has failed. Here are few suggestions that are quite cheap and easy to acquire in improving the quality of education facilities of distance learning for the rural area students in case of any pandemic or disaster situation. The mean and way of providing the education facility to rural area students should be replaced. In my view, radio is the effective efficient accessible way of communication in providing education. The books or hard copies should be provided to the students. A timetable of delivering lectures should be given to the students along with books. In financial way, HEC should provide books and hard material within the paid fees.
\end{abstract}

Contribution/ Originality: The contribution of this study which has investigated the impact of Covid-19 on education of rural area of student: moderating role of HEC policy and internet service in case of Pakistan. This study contributes in Covid-19 literature and gives the solution of problem which Pakistani student face in rural area in case of online classes and internet service.

\section{INTRODUCTION}

First, World Health Organization was declaring the disease with the name of novel corona virus on December 8 in the city of Wuhan, China that made panic in everywhere ( $\mathrm{Zu}$ et al., 2020) At that time, China was ready to celebrate their New Year "Spring Festival", when the virus was spread rapidly with the movement of people one city to another city (Chen, Yang, Yang, Wang, \& Bärnighausen, 2020). When this festival come people move to their home cities, due to this shuffling/movement of people this virus spread all over the world. So, the result of this movement, this virus spread dreadful effects on human body and economic (Baker et al., 2020). 
WHO declare that there is no specific medication or vaccination of this disease (Sohrabi et al., 2020)? With the passage of time, this virus was resurrection all over the world (Purcell \& Charles, 2020). Firstly, these viruses distort the artificial beauty of the world and shutdown the world (Mhalla, 2010). Secondly, they badly damage the educational system. Education is the soul of the economy. Education is considered as developing weapon of an economy. Many scholars contributed to solve the problem of developed and developing country on education during covid-19 (Porpiglia. et al., 2020; Rundle, Park, Herbstman, Kinsey, \& Wang, 2020; Viner et al., 2020). In many article scholars show the impact of corona virus between developed and developing (Loayza \& Pennings, 2020). Due to lack of social distance in developing country corona cause more disaster as to compare to developed country (Meunier, 2020). Developed countries like Germany, Italia and USA also face the side effects of corona virus (Alvarez, Argente, \& Lippi, 2020). Mostly scholar shows significant impact of COVID-19 because in developing countries per capita income is below in poverty line (Bong et al., 2020).

Epidemic COVID-19 is a monstrous geopolitical disturbance that will reset the universal framework once the fuzz is lifted, quicken de-globalization just as de-regionalization, and set up new political furthermore, trade alignments and most likely another world request (Nawaz, Yun, Nawaz, \& Aalam, 2020). There is differing expectation that the new corona virus will reframe world monetary utilization and creation chains. Due to the outrageous episode, the worldwide economy is anticipated to break this year (Sohrabi et al., 2020). Be that as it may, Chinese pioneers put stock in the development and progress in controlling corona virus is proof of the responsibility to situate China as the forefront head in the overall battle over the infection, and to walk toward developing a worldwide force (Kowalski et al., 2020). Corona virus appears to have gotten a driving on-screen character in foreign relations. It will reshape worldwide conciliatory arrangements, said by Mohammad Tabatabaei.

The contribution of this study in covid-19 literature that investigated the how covid-19 damage the education sector of Pakistan countries. This qualitative study investigates the impact of Covid-19 on students of Pakistani rural areas. The result argues that Covid-19 has negative impact on rural areas students of Pakistan under the online education strategy. Pakistan is a developing country, however Pakistan unable to run the online education approach like China, USA, EU countries. Further has extension in this way problems. This study other parts arrange in this style; $2^{\text {nd }}$ part represents to literature review portion, 3rd part represents Courantyne strategy, $4^{\text {th }}$ part represents HEC strategy $5^{\text {th }}$ part represent conclusion.

\section{LITERATURE REVIEW}

This study investigates the impact of covid-19 on educational sector evidence of Pakistan. Many scholars work on covide-19 and investigate in previous studies. For example, Wajdi et al. (2020) used primary data to discuss the policy of the government on the education system during the pandemic situation (Covid-19). Government policymakers suggest the online lectures school and university level schedule apply for students. The government takes a step to cancel the examination activity of 2020. Coronaviruses are a gathering of related infections that cause illnesses in warm-blooded animals and flying creatures. In people, coronaviruses cause respiratory tract contaminations that can be gentle, for example, a few instances of the basic cold (among other potential causes, prevalently rhinoviruses), and others that can be deadly, for example, SARS, MERS, and COVID-19 (Gao, Tian, \& Yang, 2020; Hageman, 2020; Sun, Lu, Xu, Sun, \& Pan, 2020; Velavan \& Meyer, 2020). Manifestations in different species shift: in chickens, they cause an upper respiratory tract illness, while in cows and pigs, they cause looseness of the bowels. There are yet to be antibodies or antiviral medications to forestall or treat human coronavirus diseases.

Corona viruses establish the subfamily Ortho coronavirinae, in the family Coronaviridae, request Nidovirales, and domain Riboviria. They have encompassed infections with a positive-sense single-abandoned RNA genome and a nucleocapsid of helical balance. The genome size of coronaviruses ranges from roughly 27 to 34 kilobases, the biggest among known RNA viruses (Geller, Varbanov, \& Duval, 2012; Sexton et al., 2016; Sturman \& Holmes, 
1983). The name coronavirus is gotten from the Latin crown, signifying "crown" or "radiance", which alludes to the trademark appearance suggestive of a sun oriented crown around the virions (infection particles) when seen under two-dimensional transmission electron microscopy, because of the surface being canvassed in club-molded protein spikes. Coronavirus sickness (COVID-19) is an irresistible malady brought about by a newfound coronavirus (Chen et al., 2020; Touret \& Lamballerie, 2020; Zheng, Ma, Zhang, \& Xie, 2020). As of now, there are no antibodies or medicines for COVID-19. In any case, there are numerous progressing clinical preliminaries assessing possible medicines. WHO will keep on giving refreshed data when clinical discoveries become accessible?

\subsection{Courantyne Strategy Analysis in Corona Virus Management}

Lockdown is a crisis convention to forestall individuals, gatherings of individuals, or networks from being enormous, leaving or entering from or to a region. Lockdown conventions must be set up by specialists.

In the security setting, Lockdown can mean separating a territory. This convention, abroad, is frequently applied in schools or in open offices, for example, medical clinics in case of a matter of power majeure. On account of Corona, Lockdown has the closeness of significance in the term isolate area, as specified in Law No. 6 of 2018 on the wellbeing significance (UURI, 2018).

\subsection{In the Act it is Mentioned That}

"Regional quarantine is a resident restriction on an area including the entrance of the entry and its contents allegedly infected with disease and/or contaminated in such a way as to prevent the possibility of spreading the disease or contamination".

In article 49 the law likewise referenced isolates types, in particular: House isolate, medical clinic isolate, regional isolate and social limitation for huge scope. The protection is: "The detachment of debilitated individuals from sound individuals is done in social insurance offices to get treatment and care."

Who is approved to brooding regional isolate? It was expressed that regional isolate limitations and social limitations for enormous scope were set up by pastors. The administration has set up a team in the treatment of Corona infections directed by the head of BNPB. The law has ordered an exceptionally vital circumstance in specific circumstances, one level under war crisis to BNPB and BPBD, that is what is designated "straightforward entry".

\subsection{In Article 55 of Law No. 24 of 2007 on Fiasco Alleviation is Referenced that}

"If there should arise an occurrence of calamity crisis status is set up, the National Agency for Disaster Management and territorial debacle the board organization has simple access which incorporates: human asset arrangement, gear sending, coordination's arrangement, movement, extract, and isolate, authorizing, acquirement of products/administrations, the executives and responsibility of cash as well as merchandise, salvage, and order to train the part/foundation UURI (2007).

\subsection{How Rural Area Students Survive in Online Classes during the Corona Virus \\ 2.4.1. Situation of Corona Virus in Pakistan}

The 2019 novel corona virus has spread to more than 213 countries and as of $17^{\text {th }}$ April 2020, 1995,983 confirmed cases and 131,037 deaths rate have been reported globally. Pakistan being sharing border with China and Iran, having high frequency of travel and trade has been at risk of viral transmission. Pakistan reported its first two ensured cases, on 26th February 2020 related with traveling history of Iran. The measure of bore observer to cases the country over rose to 7,025 on seventeenth April 2020 with 135 passing's and 3276 affirmed cases in Punjab,2008 cases in Sindh,993 in Khyber Pathunkhawa,303 in Baluchistan,237 in Gilgit Baltistan,154 in ICT and 46 in Azad Jammu Kashmir. To-date 7000 Pakistani pioneers have come back from Iran and set in detach in Taftan. Arranging of pioneers back to their urban systems without testing at the edge acknowledged presentation of infection in nation. Pakistan's frail remedial 
organizations structure with 0.6 bed for 1000 individuals and under $0.75 \%$ of GDP as success spending is flawed to drive forward through the COVID-19 incapacitate if there should rise an occasion of exponential expansion in cases.

\section{Total Coronavirus Cases in Pakistan}

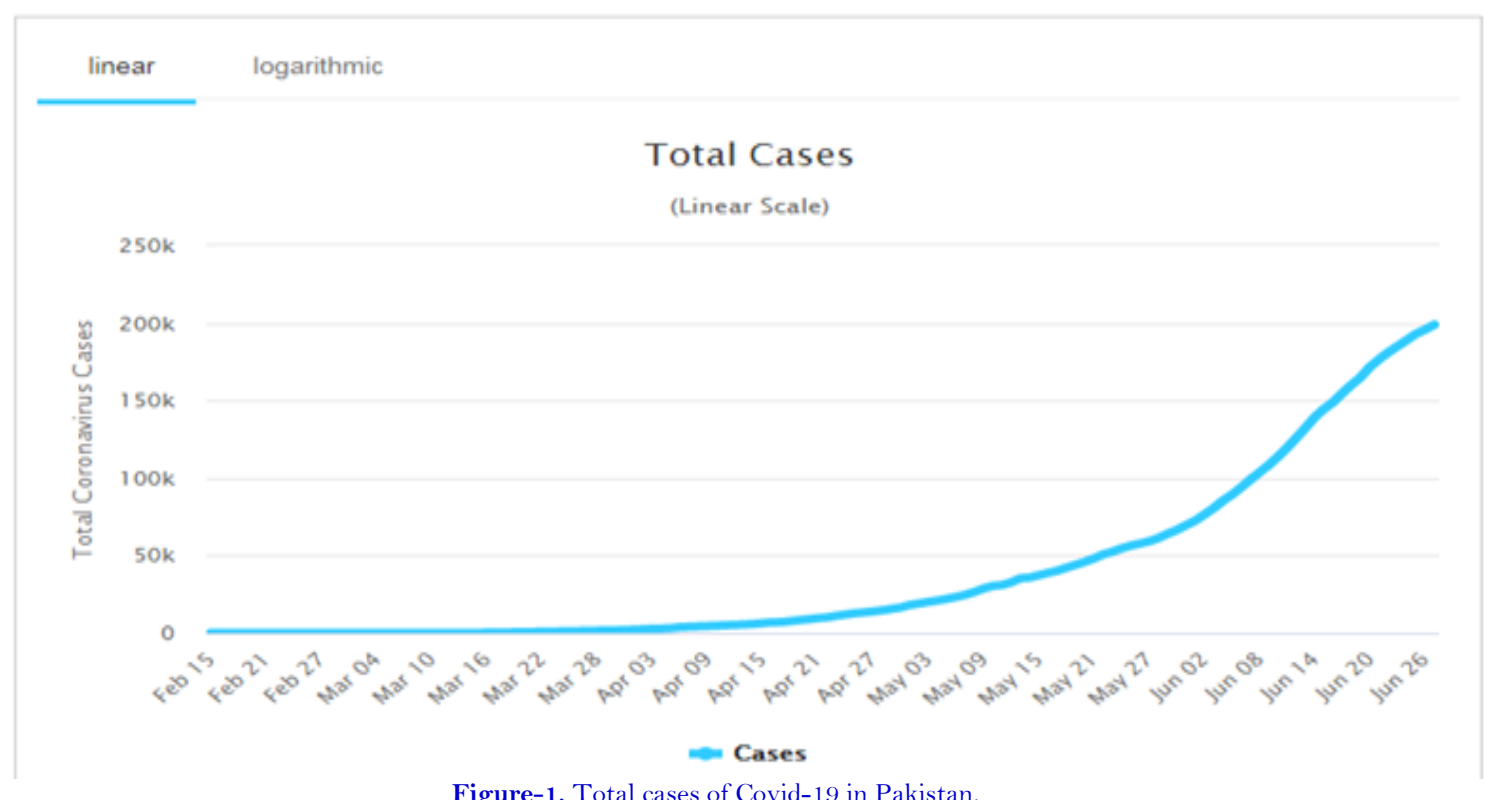

Source: https://www.worldometers.info/coronavirus/country/pakistan/

\section{Daily New Cases}

Cases per Day

Data as of 0:00 CMT+0

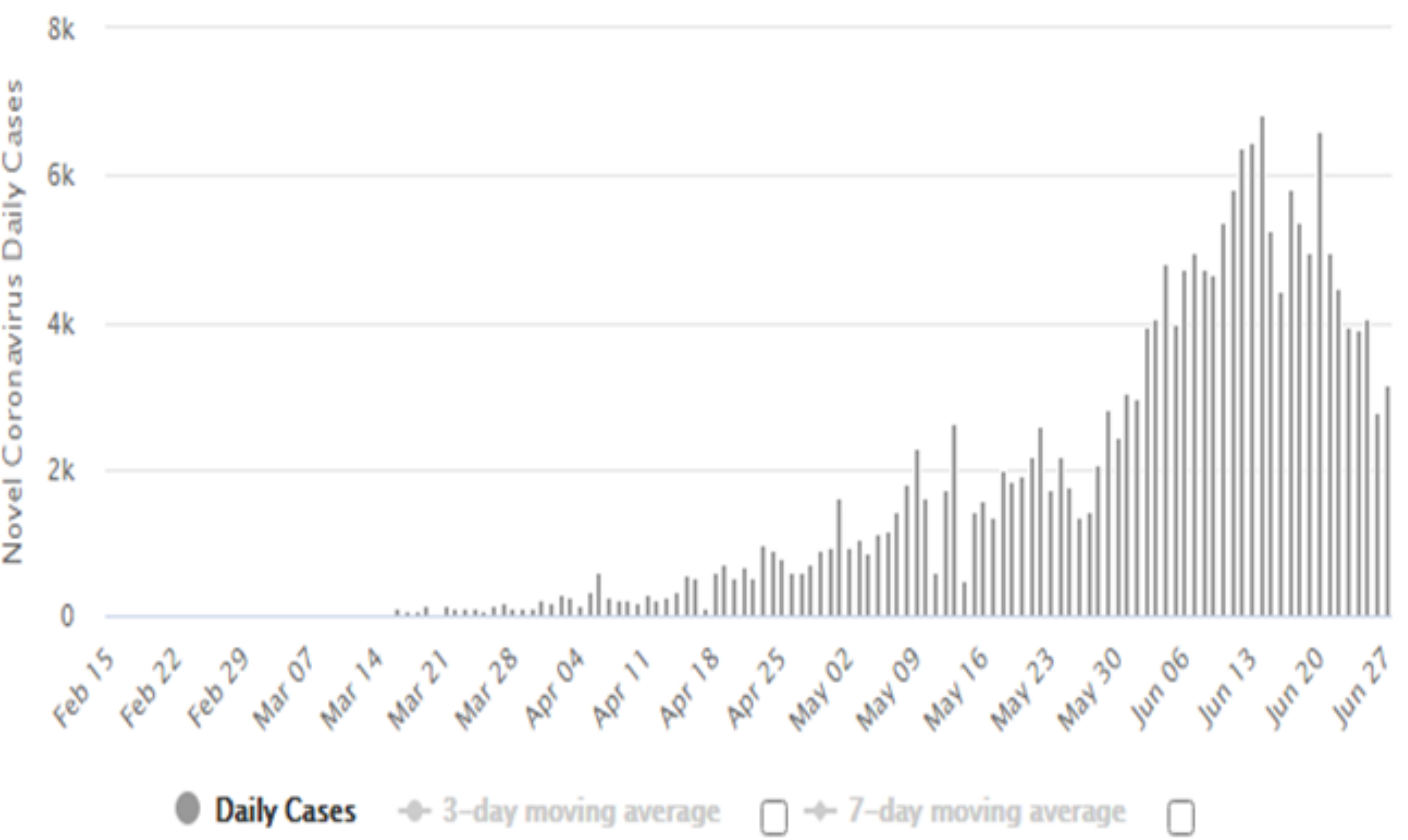

Source: Worldometers, 2020

Figure-2. Daily New cases of covid-19. 


\section{Active Cases}

(Number of Infected People)

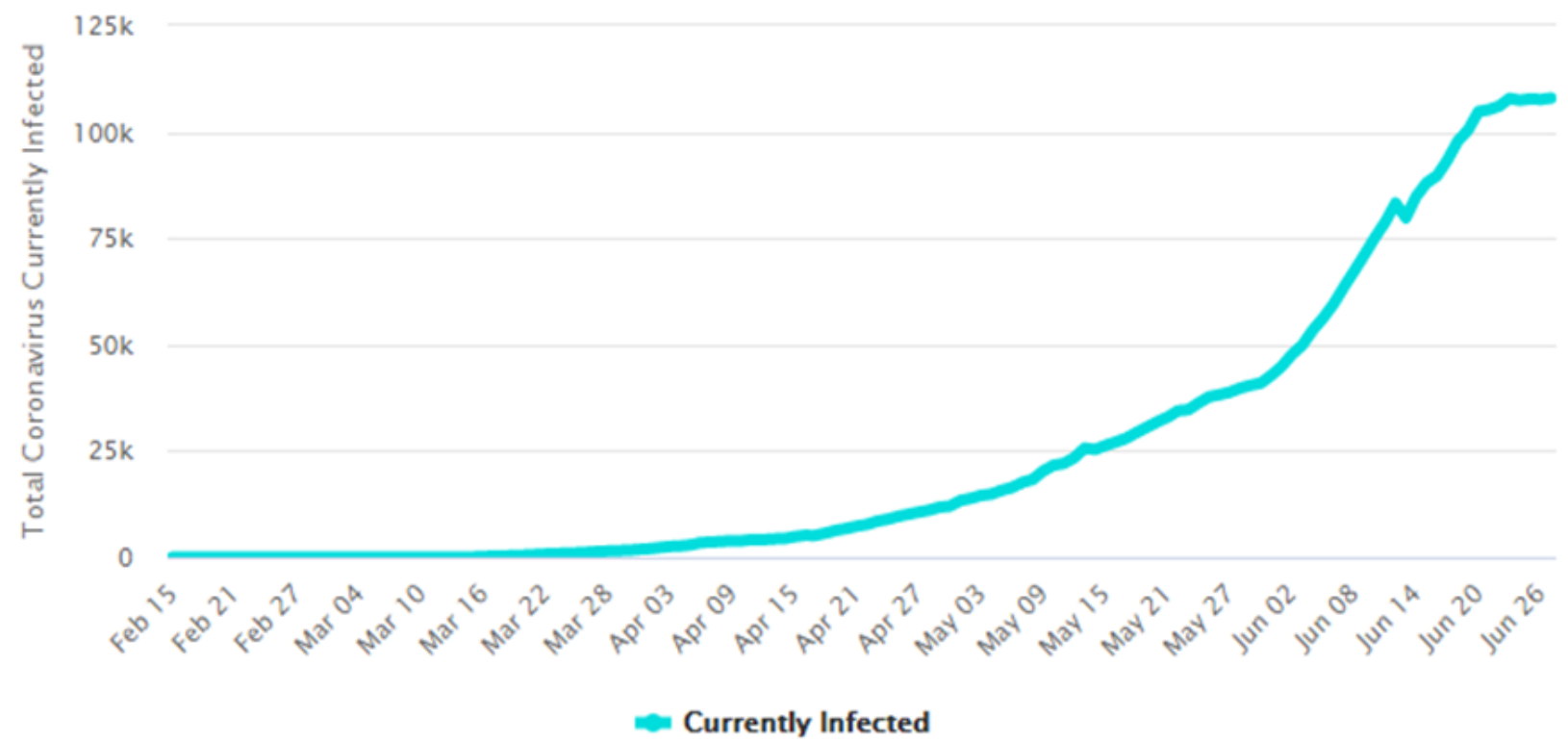

Source: Worldometers, 2020 .

Figure-3. Currently Infected cases in Pakistan.

\section{Total Coronavirus Deaths in Pakistan}

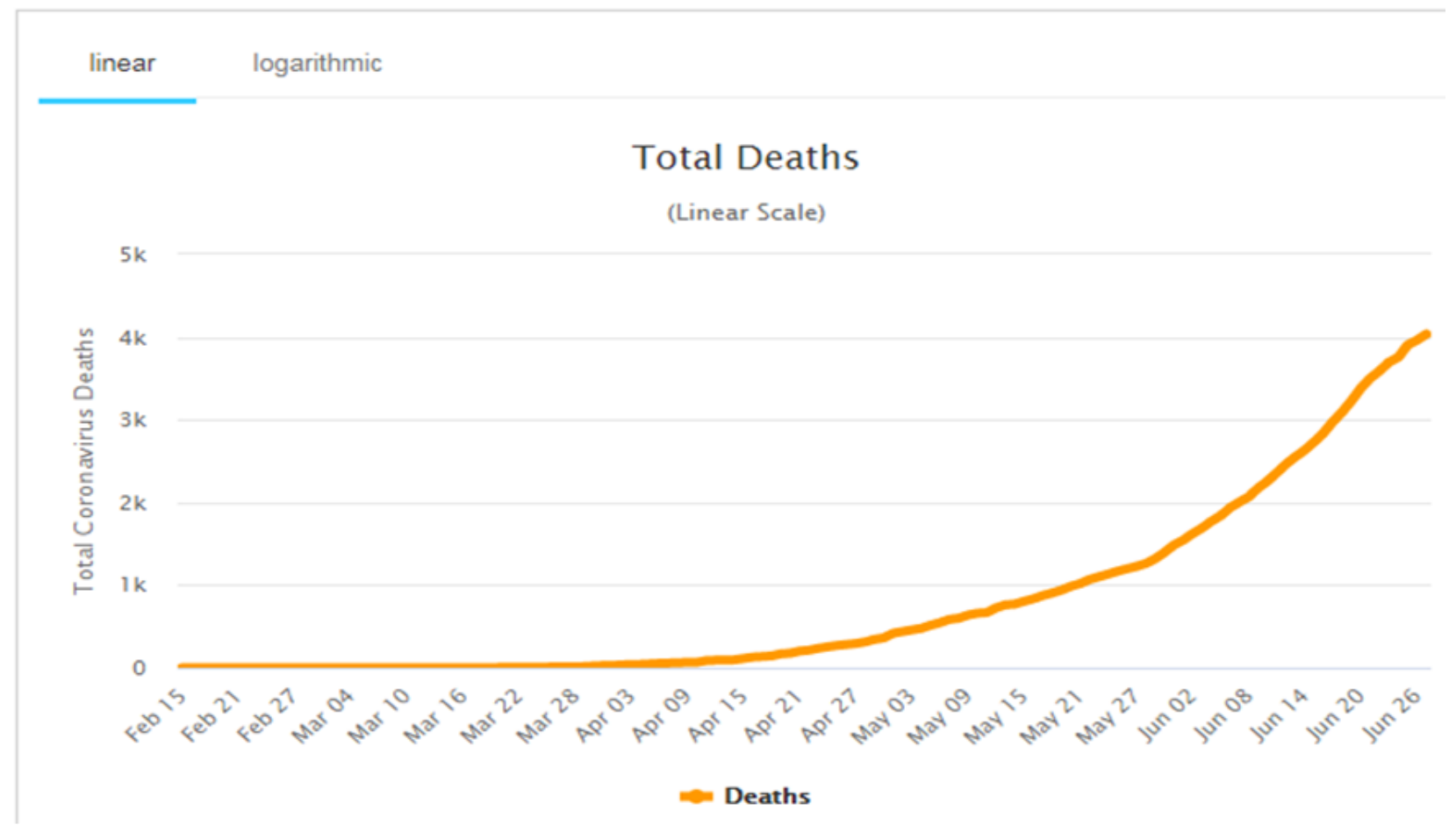

Source: Worldometers, 2020 .

Figure-4. Total Covid-19 death rate in pakistan. 


\section{Daily New Deaths in Pakistan}

\section{Daily Deaths}

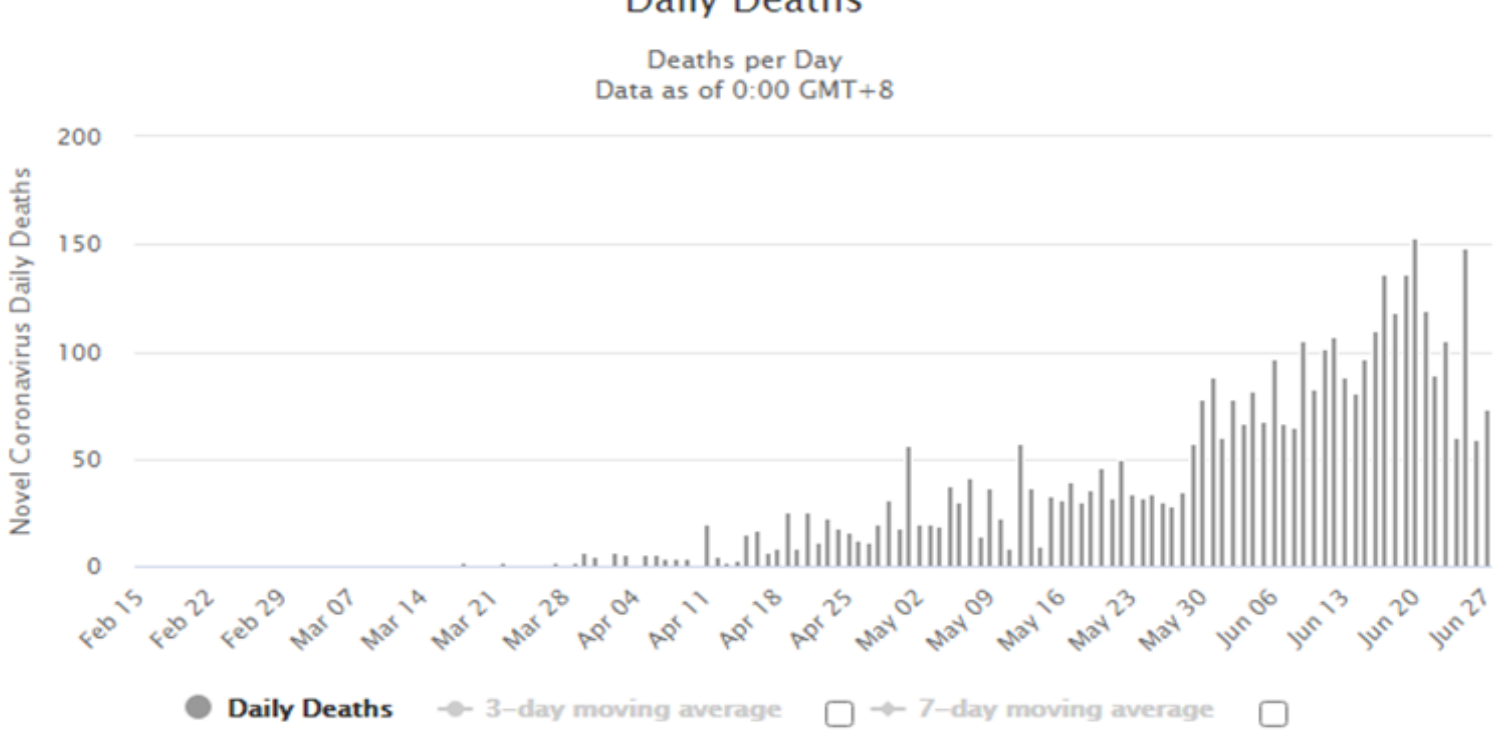

Source: Worldometers, 2020.

Figure-5. Daily death rate of covid-19 in Pakistan.

\section{Newly Infected vs. Newly Recovered in Pakistan}

\section{New Cases vs. New Recoveries}

(Number of newly infected vs. number of recovered and discharged patients each day)

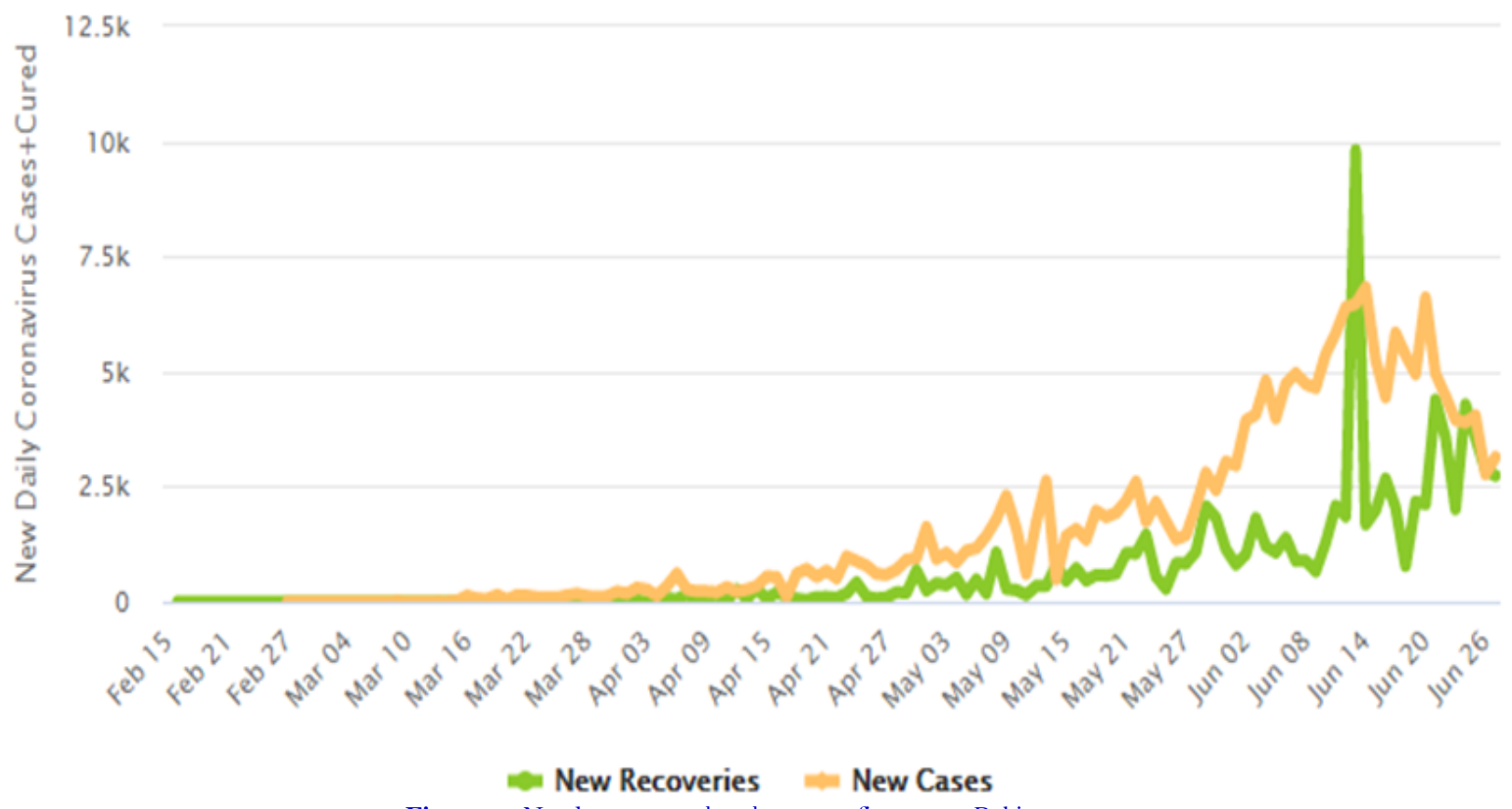

Source: Worldometers, 2020

Figure-6. Newly recovered and new confirm cases Pakistan. 


\section{Outcome of Cases (Recovery or Death) in Pakistan}

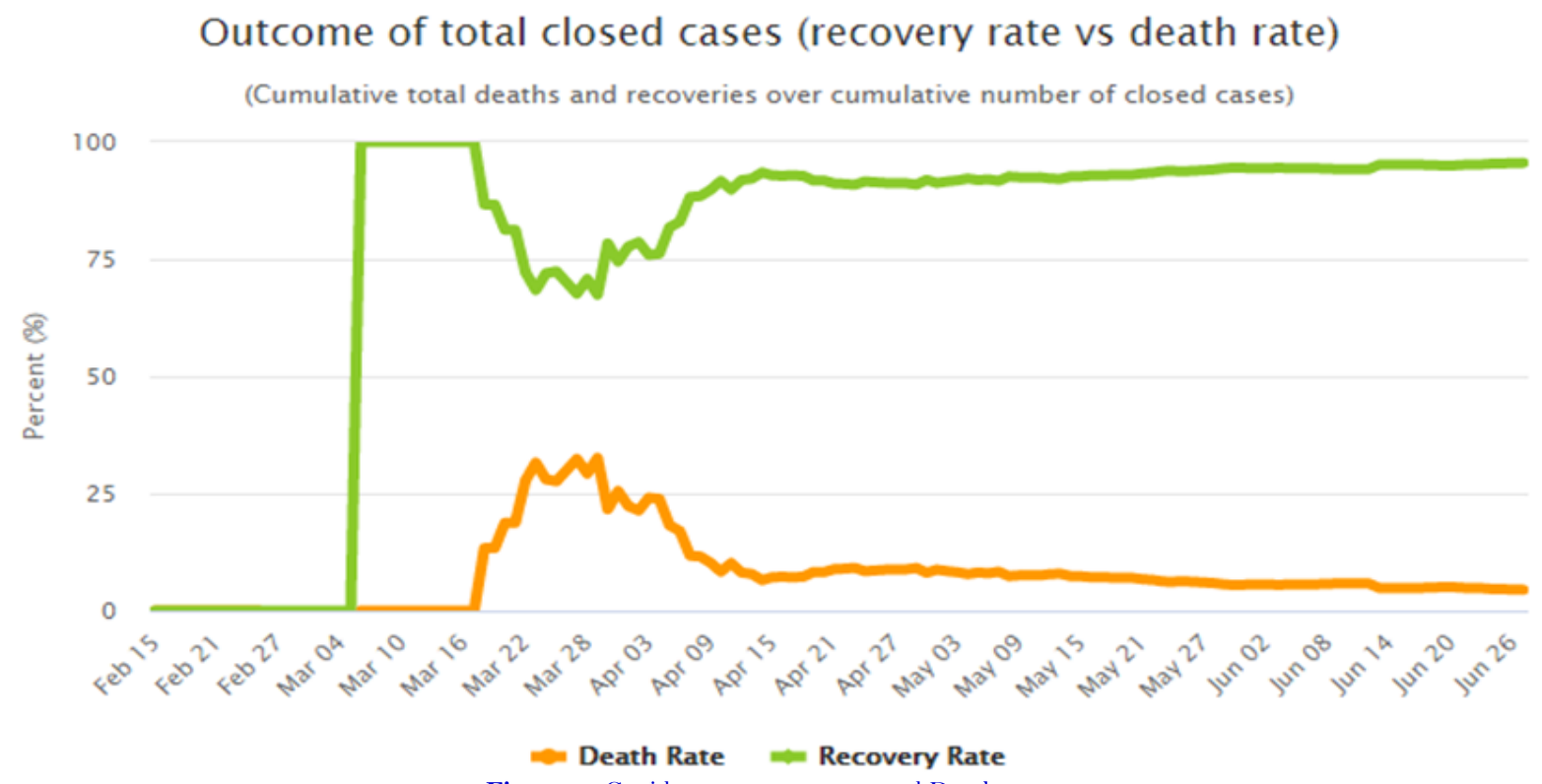

Source: Worldometers, 2020.

Figure-7. Covid-19 cases recovery and Death rate.

\subsection{Covid-19 and Education Situation in Rural Areas}

While physical distance, relative isolation, and lower population density play in favors for rural areas in conditions of the direct impact of COVID-19, as the infection spreads gradually in rural areas. Rural areas are much less ready to deal with this situation. Of the 734 million great poor before the COVID-19 crisis, 80 percent live in rural areas. Of these, 76 percent profession in agriculture. Rural inhabitants have dramatically less access to adequate sanitation, health services, education, internet and communications technology, social protection, and public infrastructure. In rural area most of the people are related to agricultural sector and some peoples are depend on hand to mouth income. So that they are not able to afford extra expanse of their children study. On the other hand, if some people are able afford this expanse but due to internet service students are not able to attend online classes properly. So, the major issue for rural area student is the low-quality internet service. Figure- 8 also mention in picture that how Pakistani students face issues in rural areas.

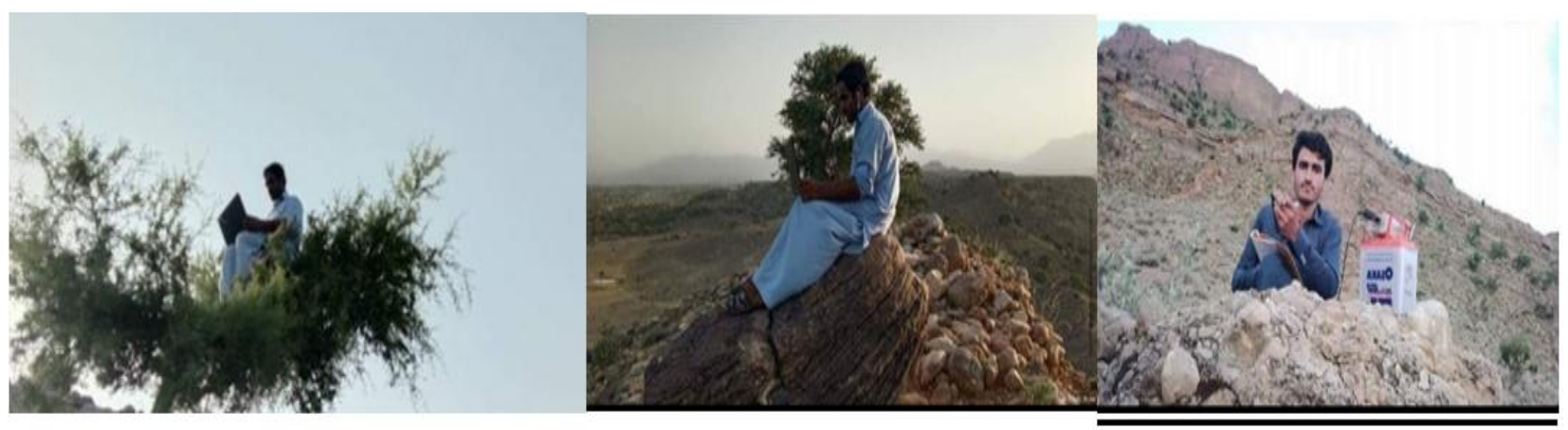

Figure-8. The rural area students taking online classes. 


\section{FRAMEWORK:}

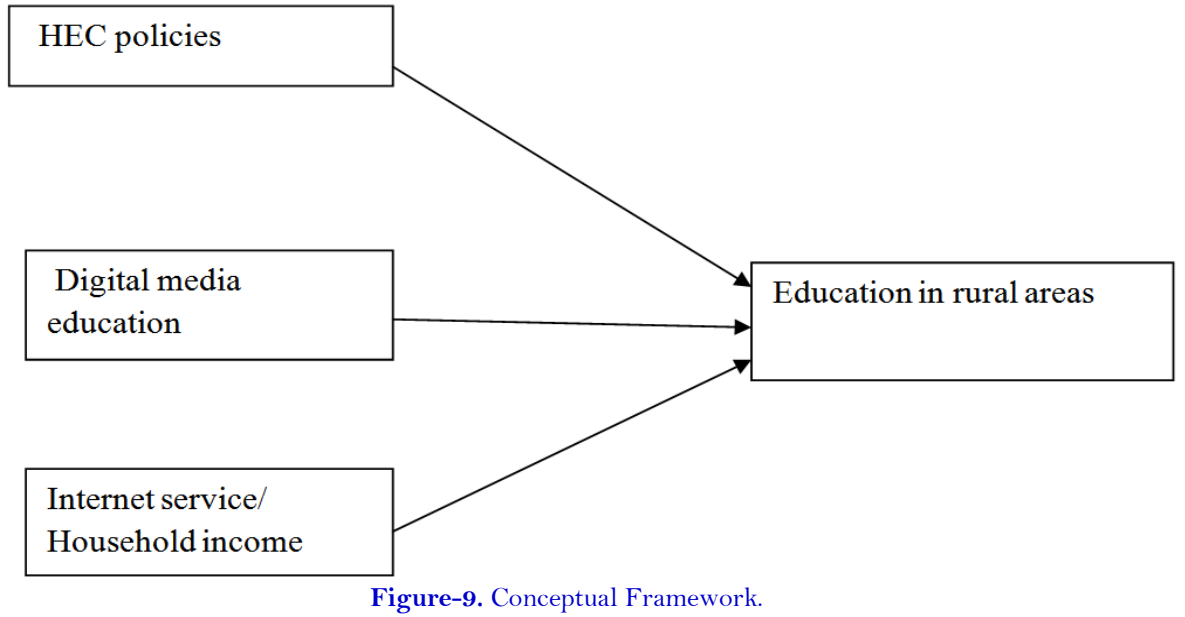

2.6. Moderating role of HEC Policy during COVID-19

HEC organized online classes for school, college, and university students during the covid-19. For this purpose, HEC send the official notice for the entire higher educational institute to establish online classes system. Due to the entire situation educational institute closed, at that time intermediate final exams are in process. For the safety of student all the exam was postpone for some time. But with the passage 'of time government announced that all the intermediate papers are canceled, and student was promoted to the next level. But now a day there is a clash between government and HEC. HEC was rejected the policy of government to promote the students to the next level. HEC play a positive role to promote the education but on the other hand HEC exploited the student rights.

\subsection{The Role of Digital Media Education}

Digital media consider as the most advance technology now these days. In different institute and the top scholar are used this technology for deliver their online tutorials and valuable knowledge. Universities are also use the social media in the teaching-learning technique to find new value for creating proper learning with students. Social media implementation is giving way to the development of the new educational system. Students are repeatedly exchanging their thoughts and knowledge with each other through social media.

\subsection{Positive Impact of Digital Media on Education}

Learning process is different in digital media. New generation are more interconnected and better informed. Due to positive impact of digital media, it is very easy to work as a group for project assignments by using social networking. Students make different groups on different social networks like what's aap; twitter; face book and email to share input regarding to the assignment. Knowledge is affecting at an escalating rapidity with the usage of digital media in education.

\subsection{Negative impact of Digital media on Education}

Social media is also having negative effects on students. New generations are addicted to this medium. Students waste most of their time on social networks. They distract from their actual aim. It is taking them away from books and limiting their mind. Communication skills are distorting due to the excess use of social media. Whether these things are totally negative to the social order is however to be seen, but there are some benefits of social media that self-confidently influence students' outcomes. 


\subsection{HEC and Government If Apply New Policy Then the Face Following these Issues}

Many scholars contribute to solve the following issue that the developed and developing countries facing during COVID-19. But the main serious issue was education in the entire world. So, resolving this issue many scholars doing work on it how the developing and developed countries make different straightly to overcome this issue during corona virus. Some scholar talks about China government policy that they apply to overcome these issues. China introduce the online lectures system to overcome the education lose during corona virus. Some of developed countries like Germany, Italy and USA also copy China methodology to overcome the loss of education. Our area of research is relating with Pakistan in which Higher education commutation also impose different policies to overcome the loss of education during corona virus. But HEC failed to solve the education problem throughout COVID-19. If the Government or HEC apply these new policies to improve the system then they face the following issue in rural areas.

\subsection{Internet Devices}

If Government or HEC provide the internet devices to the students with unlimited MBs or free of cost to overcome the loss of education. If HEC impose this policy then they face the issue of internet service, because most of the rural areas have no broadband connection. So this policy is not suitable for these rural areas.

\subsection{Telecomm Service}

If Government or HEC use the service of telecomm to overcome the loss of education. If HEC impose this policy and order all the educational institute and cable network to play the video lectures on TV. If HEC impose this policy then they face the issue of electricity, because most of the rural areas have no electricity connection. So this policy is not suitable for these rural areas and situation education during corona virus is same.

\section{CONCLUSION}

This qualitative study reported that Pakistan Government has declared that it will give the best effort in dealing with corona or COVID-19 viruses. The government is an actual present to protect its society in a secure the safety of every citizen. The government's efforts deserve the support of all Pakistani. Because with unity, teamwork, Pakistan believes it can solve the problem of deployment of COVID-19. In the field of education, the government and Higher education commutation imposes some of the policies facing Corona virus. This is all done to minimize the spread of corona virus and overcome the loss of education. Because Education is considered as the backbone of any economy. For developing countries Education is the great weapon to improve their economy. Now a day's Pakistan fights with COVID-19. Pakistan is considered in the list of developing countries with low resources. That's the main reason Pakistan face many problem and education is the biggest issue which destroy the economy of Pakistan now these days. Because Pakistan education commutations have low resources and $70 \%$ of peoples live in rural areas. In rural areas there are no facilities, so the rural areas student faces many problems. Due to this situation most of the students who belong from rural areas drop his education because of no internet service to continue their online classes.

\section{SUGGESTION}

If Government of Pakistan applies the following policies so they overcome the education issue in rural areas during COVID-19.

\subsection{Hard Material}

If government or Higher education commutation apply hard material policy in all the educational institutes as we already familiar to this technology. In Pakistan Allama Open University already use this technique. If all 
educational institutes provide free of cost hard material to the students especially for rural areas students, so the Government of Pakistan will overcome the loss of education during these critical days.

4.2. Radio

In the same way if government apply the radio technology in education sector and odder to the institute to deliver lecture through radio for some specific hours. So due to this technology Government resolve the education issue during corona virus. Because this technology was use in every single area of Pakistan.

Funding: This study received no specific financial support.

Competing Interests: The authors declare that they have no competing interests.

Acknowledgement: All authors contributed equally to the conception and design of the study.

\section{REFERENCES}

Alvarez, F. E., Argente, D., \& Lippi, F. (2020). A simple planning problem for covid-19 lockdown (No. w26981). National Bureau of Economic Research.

Baker, S. R., Bloom, N., Davis, S. J., Kost, K. J., Sammon, M. C., \& Viratyosin, T. (2020). The unprecedented stock market impact of COVID-19 (No. w26945). National Bureau of Economic Research.

Bong, C.-L., Brasher, C., Chikumba, E., McDougall, R., Mellin-Olsen, J., \& Enright, A. (2020). The COVID-19 pandemic: Effects on low-and middle-income countries. Anesthesia and Analgesia, 131(1), 86-92. Available at: https://doi.org/10.1213/ane.0000000000004846.

Chen, S., Yang, J., Yang, W., Wang, C., \& Bärnighausen, T. (2020). COVID-19 control in China during mass population movements at New Year. The Lancet, 395(10226), 764-766. Available at: https://doi.org/10.1016/s01406736(20)30421-9.

Gao, J., Tian, Z., \& Yang, X. (2020). Breakthrough: Chloroquine phosphate has shown apparent efficacy in treatment of COVID19 associated pneumonia in clinical studies. BioScience Trends, 14(1), 72-73. Available at: https://doi.org/10.5582/bst.2020.01047.

Geller, C., Varbanov, M., \& Duval, R. E. (2012). Human coronaviruses: Insights into environmental resistance and its influence on the development of new antiseptic strategies. Viruses, 4(11), 3044-3068. Available at: https://doi.org/10.3390/v41 13044 .

Hageman, J. R. (2020). The coronavirus disease 2019 (COVID-19). In Pediatric Annals. Available at: https://doi.org/10.3928/19382359-20200219-01.

Kowalski, L. P., Sanabria, A., Ridge, J. A., Ng, W. T., de Bree, R., Rinaldo, A., . . Bradford, C. R. (2020). COVID-19 pandemic: Effects and evidence-based recommendations for otolaryngology and head and neck surgery practice. Head $\mathcal{E}^{\circ}$ Neck, 42(6), 1259-1267.

Loayza, N. V., \& Pennings, S. (2020). Macroeconomic policy in the time of COVID-19: A primer for developing countries. Available at: https://doi.org/10.1596/33540.

Meunier, T. A. (2020). Full lockdown policies in Western Europe countries have no evident impacts on the COVID-19 epidemic. MedRxiv. Available at: https://doi.org/10.1101/2020.04.24.20078717.

Mhalla, M. (2010). The impact of novel coronavirus (COVID-19) on the global oil and aviation markets. Journal of Asian Scientific Research, 10(2), 96.

Nawaz, S., Yun, J., Nawaz, M. Z., \& Aalam, F. (2020). Is COVID-19 generating pandemic animosity among nations and consumers? A theoretical overview. RMC Journal of Social Sciences and Humanities, 1(1), 44-50. Available at: https://doi.org/10.46256/rmcjsochum.vii1.83.

Porpiglia., F., Checcucci, E., Amparore, D., Verri, P., Campi, R., Claps, F., \& Mario, S. R. (2020). Slowdown of urology residents' learning curve during the COVID-19 emergency. BJU International. Available at: https://doi.org/10.1111/bju.15076. 
Purcell, L. N., \& Charles, A. G. (2020). An invited commentary on world health organization declares global emergency: A review of the 2019 novel coronavirus (COVID-19). Emergency or new Reality? International Journal of Surgery London, England, 76, 111. Available at: https://doi.org/10.1016/j.ijsu.2020.02.034.

Rundle, A. G., Park, Y., Herbstman, J. B., Kinsey, E. W., \& Wang, Y. C. (2020). COVID-19-related school closings and risk of weight gain among children. Obesity, 28(6), 1008-1009. Available at: https://doi.org/10.1002/oby.22813.

Sexton, N. R., Smith, E. C., Blanc, H., Vignuzzi, M., Peersen, O. B., \& Denison, M. R. (2016). Homology-based identification of a mutation in the coronavirus RNA-dependent RNA polymerase that confers resistance to multiple mutagens. Journal of Virology, 90(16), 7415-7428. Available at: https://doi.org/10.1128/jvi.00080-16.

Sohrabi, C., Alsafi, Z., O’Neill, N., Khan, M., Kerwan, A., Al-Jabir, A., . . Agha, R. (2020). World health organization declares global emergency: A review of the 2019 novel coronavirus (COVID-19). International Journal of Surgery, 76, 71-76. Available at: https://doi.org/10.1016/j.ijsu.2020.02.034.

Sturman, L. S., \& Holmes, K. V. (1983). The molecular biology of coronaviruses. Advances in Virus Research, $28(\mathrm{C}), 35-112$. Available at: https://doi.org/10.1016/So065-3527(08)60721-6.

Sun, P., Lu, X., Xu, C., Sun, W., \& Pan, B. (2020). Understanding of COVID-19 based on current evidence. In Journal of Medical Virology, 92(6), 548-551. Available at: https://doi.org/10.1002/jmv.25722.

Touret, F., \& Lamballerie, X. (2020). Of chloroquine and COVID-19. In Antiviral Research. Available at: https://doi.org/10.1016/j.antiviral.2020.104762.

UURI. (2007). Undang-undang republik indonesia nomor 24 tahun 2007 tentang penanggulangan bencana.

UURI. (2018). UU No. 6 Year 2018 concerning health quarantine. Retrieved from: https://peraturan.bpk.go.id/Home/Details/90037/uu-no-6-tahun-2018

Velavan, T. P., \& Meyer, C. G. (2020). The COVID-19 epidemic. In Tropical Medicine and International Health. Available at: https://doi.org/10.1111/tmi.13383.

Viner, R. M., Russell, S. J., Croker, H., Packer, J., Ward, J., Stansfield, C., \& Booy, R. (2020). School closure and management practices during coronavirus outbreaks including COVID-19: A rapid systematic review. The Lancet Child \& Adolescent Health, 5(4), 397-404.

Wajdi, M. B. N., Kuswandi, I., Al Faruq, U., Zulhijra, Z., Khairudin, K., \& Khoiriyah, K. (2020). Education policy overcome coronavirus, A study of Indonesians. EDUTEC: Journal of Education And Technology, 3(2), 96-106.

Zheng, Y. Y., Ma, Y. T., Zhang, J. Y., \& Xie, X. (2020). COVID-19 and the cardiovascular system. In Nature Revierws Cardiology. Available at: https://doi.org/10.1038/s41569-020-0360-5.

Zu, Z. Y., Jiang, M. D., Xu, P. P., Chen, W., Ni, Q. Q., Lu, G. M., \& Zhang, L. J. (2020). Coronavirus disease 2019 (CO VID-19): A perspective from China. Radiology, 200490

Views and opinions expressed in this article are the views and opinions of the author(s), Asian Journal of Contemporary Education shall not be responsible or answerable for any loss, damage or liability etc. caused in relation to/arising out of the use of the content. 